\title{
Erratum to: Respiratory consequences of N95-type Mask usage in pregnant healthcare workers-a controlled clinical study
}

Pearl Shuang Ye Tong ${ }^{1}$, Anita Sugam Kale ${ }^{1}$, Kailyn Ng${ }^{1}$, Amelia Peiwen Loke ${ }^{1}$, Mahesh Arjandas Choolani', Chin Leong Lim², Yiong Huak Chan ${ }^{3}$, Yap Seng Chong ${ }^{1}$, Paul Anantharajah Tambyah ${ }^{4}$ and Eu-Leong Yong ${ }^{4^{*}}$

\section{Erratum}

The original article [1] listed the clinicaltrials.gov identifier in the Trial Registration sub-section as NCT00265926; this identifier should instead have read 'NCT02265926'.

\section{Author details}

${ }^{1}$ Department of Obstetrics and Gynecology, National University Hospital, 11 Mandalay Road, Singapore 308232, Singapore. ${ }^{2}$ Lee Kong Chian School of Medicine, Nanyang Technological University, 11 Mandalay Road, Singapore 308232, Singapore. ${ }^{3}$ Biostatistics Unit, National University of Singapore, Singapore, Republic of Singapore. ${ }^{4}$ Medicine, National University of

Singapore, 1 E Kent Ridge Road, Level 12, Singapore 119228, Singapore.

Received: 25 January 2016 Accepted: 28 June 2016

Published online: 04 July 2016

\section{Reference}

1. Ye Tong PS, Kale AS, Ng K, Loke AP, Choolani MA, Lim CL, Chan YH, Chong YS, Tambyah PA, Yong E-L. "Respiratory consequences of N95-type Mask usage in pregnant healthcare workers-a controlled clinical study". Antimicrob Resist Infect Control. 2015;4:48. http://doi.org/10.1186/s13756015-0086-z.

\footnotetext{
* Correspondence: obghead@nus.edu.sg

${ }^{4}$ Medicine, National University of Singapore, 1 E Kent Ridge Road, Level 12, Singapore 119228, Singapore

Full list of author information is available at the end of the article

Submit your next manuscript to BioMed Central and we will help you at every step:

- We accept pre-submission inquiries

- Our selector tool helps you to find the most relevant journal

- We provide round the clock customer support

- Convenient online submission

- Thorough peer review

- Inclusion in PubMed and all major indexing services

- Maximum visibility for your research

Submit your manuscript at www.biomedcentral.com/submit 